\title{
VAMOS program: instruments for measuring physical activity, feeding and anthropometry
}

\section{Programa VAMOS: instrumentos para medida de atividade física, alimentação e antropometria}

\author{
Mônica Costa Silva ${ }^{1}$ \\ (D) https://orcid.org/0000-0002-9492-7610 \\ Cezar Grontowski Ribeiro ${ }^{1,2}$ \\ (D) https://orcid.org/0000-0003-0640-3110 \\ Tânia Rosane Bertoldo Benedetti ${ }^{1}$ \\ (DD https://orcid.org/0000-0002-2035-5082
}

Abstract - The aim of this study was to indicate instruments to measure the effectiveness of the Active Life Improving Health Program - VAMOS, in physical activity (PA), feeding and anthropometry. Fifty-six participants were selected to act as analysts in the different stages of the work: 1) systematic review, 2) consensus groups, 3) analysis of selected instruments, 4) focus group. Physical activity, feeding and anthropometry measures, considering their applicability, viability and low cost, were selected to be applied in the VAMOS program in Basic Health Units (UBS). Step 1: Systematic literature review selected the instruments most used to evaluate PA, feeding and anthropometry, organizing a matrix based on established criteria. Step 2: consensus groups performed the choice of the main instruments in the matrix, excluding the two less viable. Step 3: Experts from the five regions of Brazil selected the main instruments included in the matrix, excluding the two least viable ones. Step 4: The focus group established the instruments that were most feasible for use in UBS. The instruments selected to verify effectiveness in physical activity were IPAQ short-version and pedometer for feeding the VIGITEL questionnaire, for anthropometric variables body mass, height, waist circumference and body mass index. The technical and scientific process carried out allows inferring that the VAMOS program should use the above mentioned instruments to measure effectiveness within criteria of applicability, viability and low-cost.

Key words: Anthropometry; Healthy diet; Motor activity.

Resumo - Objetivou-se indicar instrumentos para mensurar a efetividade do programa Vida Ativa Melhorando a Saúde - VAMOS, na atividade física (AF), alimentação e antropometria. Foram selecionados 56 participantes para atuar como analistas nas diferentes etapas de trabalho: 1) revisão sistemática, 2) grupos de consenso, 3) análise dos instrumentos selecionados, 4) grupo focal. Foram selecionadas medidas de avaliação da atividade física, alimentação e antropometria, considerando sua aplicabilidade, viabilidade e baixo custo, para serem aplicados no programa VAMOS nas Unidades Básicas de Saúde (UBS). Etapa 1: a revisão sistemática da literatura e seleção dos instrumentos mais utilizados para avaliar AF, alimentação e antropometria, organizando uma matriz a partir dos critérios estabelecidos.Etapa 2: grupos de consenso realizaram a escolha dos principais instrumentos constantes da matriz, excluindo os dois menos viáveis. Etapa 3: especialistas das cinco regiões do Brasil selecionaram os principais instrumentos constantes da matriz, excluindo os dois menos viáveis. Etapa 4: o grupo focal estabeleceu os instrumentos que eram mais viáveis para utilização nas UBS.Os instrumentos selecionados para verificar a efetividade na atividade física foram o IPAQ versão curta e o pedômetro, para a alimentação o questionário VIGITEL, para a antropometria massa corporal, estatura, perímetro da cintura e índice de massa corporal. O processo técnico e científico realizado permite afirmar que o programa VAMOS deve utilizar os instrumentos citados para mensurar a efetividade dentro dos critérios aplicabilidade, viabilidade e baixo custo.

Palavras-chave: Alimentação saudável; Antropometria; Atividade física.
1. Federal University of Santa Catarina. Florianópolis, SC. Brazil.

2. Federal Institute of Paraná. Palmas, PR. Brazil.

Received: September 16, 2018 Accepted: April 09, 2019

How to cite this article Silva MC, Ribeiro CG, Benedetti TR. VAMOS program: instruments for measuring physical activity, feeding and anthropometry. Rev Bras Cineantropom Desempenho Hum 2020, 22:e58256. DOI: http://dx.doi.org/10.1590/19800037.2020v22e58256

Copyright: This work is licensed under a Creative Commons Attribution 4.0 International License. 


\section{INTRODUCTION}

The National Health Promotion Policy (PNPS) indicates priority themes to be developed in Brazil, and the promotion of adequate and healthy food, physical activity and body practices, are among the main actions ${ }^{1,2}$. Even with government incentives and funding, large population actions aimed at adopting healthy lifestyle have not been successfully reached. In addition, most programs are offered through systematic (traditional) physical activities, that is, dependent on a PA professional, which are expensive and have low reach ${ }^{3}$.

Regarding costs, the low number of people reached and difficulties of adhering to these programs, more attention and resources have been directed to programs that motivate behavior change. The Brazilian Vida Ativa Melhorando a Saúde - VAMOS program is highlighted, which was developed with the objective of motivating people to adopt an active and healthy lifestyle (http://vamos.ufsc.br/).

To evaluate the VAMOS program, both individually and organizationally, the "RE-AIM" tool (Reach -Effectiveness -Adoption - Implementation- Maintenance) was used. This tool assesses scope, efficacy / effectiveness, adoption, implementation and maintenance domains $s^{4,5}$.

The evaluation of the program efficacy / effectiveness deals with the impact of an intervention at individual level on some outcomes ${ }^{5}$ and, therefore, choosing appropriate instruments to carry it out becomes of paramount importance. Different measures have been used to evaluate other editions of the VAMOS program ${ }^{3}$, but professionals who worked with this program diagnosed that instruments were long and complex, making their application in the routine of Basic Health Units (UBS) difficult.

In addition, the instruments adopted are often unable to answer whether the program is actually effective ${ }^{6}$.

In this sense, the VAMOS program team felt the need to adapt and use instruments according to the opinions of experts and professionals working at UBS to technically and scientifically support the effectiveness measures in the VAMOS program.

Therefore, the aim of the present study was to indicate instruments to measure the effectiveness of the Vida Ativa Melhorando a Saúde -VAMOS program in physical activity, feeding and anthropometry.

\section{METHOD}

This research is part of a project entitled VAMOS - Vida Ativa Melhorando a Saúde Program, approved on January 25, 2016, by the Ethics Committee in Research with Human Beings of the Federal University of Santa Catarina (CEPSH / UFSC), protocol No. 1.394.492.

\section{Participants}

Fifty-six intentionally selected individuals participated in this study, form- 
ing three distinct groups for the different stages of the process of choosing instruments.

Group 1 (G1): consensus workshop. It consisted of 35 researchers and graduate students at doctoral and master's levels, specialists in the areas of Physical Education and Nutrition, linked to the Federal University of Santa Catarina. They performed the analysis of instruments selected in the systematic review, checking the most suitable ones to be submitted to the next stage and excluding the least viable ones.

Group 2 (G2): analysis of instruments. It was composed of 17 researchers from the five Brazilian geographic regions, intentionally appointed and contacted via email, linked to different universities. They analyzed instruments selected by G1, assigning values to them and excluding those with less viability.

Group 3 (G3): focus group. It consisted of three Physical Education professionals and a Nutritionist, working in UBS of Florianópolis, who were trained for multipliers of the VAMOS program. They analyzed instruments from $\mathrm{G} 2$ and indicated the instruments most applicable in Basic Health Units according to the established criteria.

\section{Study Structuring}

The study was divided into four stages: 1 - systematic review to define the instruments to be analyzed by experts for physical activity, feeding and anthropometry; 2 - consensus workshops; 3 - analysis by experts from the five regions of Brazil; 4 - focus group with experts working in UBS.

In Stage 1, for the construction of the base matrix, a systematic review on instruments to measure physical activity, feeding and anthropometry (objective and subjective measures) was performed. Studies with behavior change programs, instruments validated for the Portuguese language and aimed at the Brazilian adult / elderly population were assessed. Details of the review were described in another study ${ }^{7}$.

Instruments were selected and a matrix was created to continue the study. Instruments were analyzed by experts according to three criteria: applicability, feasibility and cost. Applicability was defined as the ease of application and interpretation of results of a given instrument. Feasibility is the capacity to perform, develop and apply instruments for a given population. Cost is the financial value necessary to purchase and / or use a particular instrument.

Anthropometric instruments and indicators were evaluated in subsequent stages using scores from 0 to 10 , with 0 being not applicable, not feasible and high cost, and 10, very applicable, feasible and low cost. After assigning scores in the analysis matrix for each area, a discussion was held with each group in order to select the best instruments in order of relevance and / or indicate others that were not yet covered. Consensus workshops generated the matrix that was reorganized according to the evaluation and when there was indication of a new instrument or anthropometric indicator, it was added to the matrix. The average of values obtained for 
each instrument was calculated, and the two values with the lowest scores were excluded from the next stage.

In Stage 2, G1 members held three consensus workshops in the areas of physical activity, nutrition and anthropometry.

Workshops aimed at evaluating instruments selected in the systematic review of each area and / or indicate new instruments that were not found in literature, but that could be added to the matrix.

The first consensus workshop was held with six participants (professors and graduate students in the area of Nutrition), regarding the basic instruments for assessing feeding. The second consensus workshop was held with 13 participants (professors and graduate students in the area of Physical Education), who work in the area of physical activity and health, to assess instruments related to physical activity. The third workshop was held with 11 participants (professors and graduate students in the area of Physical Education), who evaluated anthropometric assessment instruments.

In Stage 3, the matrix was reorganized and an email was sent to professors participating in G2. The email consisted of a letter of introduction clarifying the research objectives and inviting for the matrix analysis, the Free and Informed Consent Form (ICF) that the respondent should sign and the matrix with physical activity, feeding and anthropometry instruments, pre-selected for application in UBS. Participants indicated the alternative consistent with the importance of each instrument and indicator. They were instructed to suggest other instruments or indicators, if they considered it necessary. From this stage, the average of values obtained for each instrument was calculated, and the two values with the lowest scores were excluded from the next stage.

Stage 4 occurred after the definition of the matrix constructed by experts, in which G3 analyzed instruments that obtained the highest scores in the evaluations of previous stages.

An email was sent to 8 UBS professionals with a presentation letter, the matrix with pre-selected instruments and their description, so that multipliers could analyze instruments and indicators. Four experts agreed to participate in the focus group, which aimed to verify which instruments and indicators were feasible for application within the UBS scope, according to established criteria, to assess the effectiveness of the VAMOS program.

The focus group was coordinated by a trained team of researchers. The score attributed to each instrument in the previous stages and the justifications for their choices were analyzed. The debate generated the final selection of instruments and indicators proposed by the group of professionals in order of indication, using the evaluation scores.

\section{Analyses}

For data obtained in G1 and G2, descriptive statistics (mean and standard deviation) was used, and the two instruments with the lowest scores in each stage were excluded from the study. Data were tabulated and analyzed using Software Statistical Package for Social Science $\left(\mathrm{SPSS}^{\circledR}\right)$, version 17.0. The 
focus group carried out with G3 was organized, categorized and treated through the content analysis proposed by Bardin ${ }^{8}$.

Three distinct phases were carried out: pre-analysis, for organizing the material and structuring the initial ideas for future actions; material exploration to encode raw data and describe the characteristics of contents; treatment of results, for categorization and interpretation of results, grouping them according to established criteria. The grouped categories were: "available time of SUS professionals"; "viability of physical activity instruments"; "viability of feeding instruments"; and, "viability of anthropometric instruments".

\section{RESULTS}

In consensus workshops, five instruments were selected to measure physical activity, one for feeding and eight for anthropometry. Two new instruments were pointed out for feeding (questionnaire used by VIGITEL and the food consumption marker from the Ministry of Health), which were not found in the systematic review.

In the consensus workshop on physical activity assessment, the IPAQ short version was the instrument with the highest overall attributed average, while the Stage of Behavior Change for Physical Activity and Exercise (EMCAFE) and the accelerometer obtained the lowest averages. Most instruments were assessed as low cost in terms of applicability and feasibility. Table 1 describes the averages of all instruments analyzed. As for applicability, the pedometer was considered the most applicable and EMCAFE was the least applicable. The most viable instrument to be applied in UBS was the pedometer and the least viable the accelerometer. The IPAQ short-version was considered the lowest cost and the accelerometer the highest cost. In this step, EMCAFE and accelerometer were excluded.

In the consensus workshop on food assessment, the Food Frequency Questionnaire (FFQ) obtained the highest average, being considered the most appropriate instrument due to its applicability, feasibility and low cost (Table 1). All instruments had low cost, while for applicability and feasibility, costs were higher. Two instruments were indicated and added: VIGITEL (questions related to feeding) and the questionnaire used in food consumption markers of the Ministry of Health. In this stage, two instruments were removed: the 24-hour recall and the Food Record.

In the consensus workshop on the assessment of anthropometric indicators, height, body mass and BMI obtained the highest overall averages, respectively. They were considered the most suitable to be applied. These measures obtained the highest applicability and viability averages, while biceps and subscapular skinfolds obtained the lowest overall averages. Regarding cost, most instruments were assessed as low cost, with the exception of skinfolds (biceps and subscapularis). In general, instruments had low cost when compared to applicability and viability. In this workshop, skinfold measurements were excluded. 
Table 1 shows the averages of all assessment instruments analyzed in each item, in order of priority.

In the third stage of the study, it was verified which instruments are most suitable to measure physical activity, feeding and anthropometric indicators as effectiveness markers of the VAMOS program in UBS.

For this stage, 15 instruments were selected, five for assessing physical activity, three for feeding and eight for anthropometry, as shown in Table 1. After assigning scores according to their applicability, feasibility and cost, instruments were analyzed according to the study area.

In physical activity, the IPAQ short-version was the most indicated instrument, while the IPAQ long-version obtained the lowest overall average, lowest applicability and feasibility. Pedometer had the highest cost. All instruments were evaluated with the best average cost regarding applicability and feasibility.

For feeding evaluation, the questionnaire used in VIGITEL obtained the highest overall average and was considered the most appropriate instrument to be applied in UBS according to the three analyzed criteria. Food consumption markers were considered the least adequate, being removed

Table 1. Instruments selected in stage 2 to measure the effectiveness markers evaluated for use in the VAMOS program, in order of priority.

\begin{tabular}{|c|c|c|c|c|}
\hline Physical Activity & Applicability & Viability & Cost & Total \\
\hline IPAQ short version & $8.23 \pm 1.01$ & $7.77 \pm 1.24$ & $9.85 \pm 0.37$ & $8.61 \pm 1.29$ \\
\hline Baecke questionnaire & $7.08 \pm 1.75$ & $6.92 \pm 2.10$ & $9.69 \pm 0.63$ & $7.90 \pm 2.04$ \\
\hline IPAQ long version & $7.15 \pm 1.28$ & $6.92 \pm 1.75$ & $9.53 \pm 0.51$ & $7.87 \pm 1.73$ \\
\hline 24-h physical activity recall & $7.23 \pm 1.42$ & $6.62 \pm 1.94$ & $9.69 \pm 0.63$ & $7.85 \pm 1.94$ \\
\hline Pedometer & $8.69 \pm 2.25$ & $8.08 \pm 250$ & $6.08 \pm 1.93$ & $7.62 \pm 2.45$ \\
\hline EMCAFE & $3.78 \pm 4.38$ & $5.15 \pm 4.49$ & $5.92 \pm 4.91$ & $4.95 \pm 4.57$ \\
\hline Accelerometer & $4.08 \pm 2.06$ & $4.38 \pm 2.18$ & $2.62 \pm 2.25$ & $4.36 \pm 2.55$ \\
\hline Total & $6.89 \pm 2.76$ & $6.53 \pm 2.76$ & $7.60 \pm 3.39$ & \\
\hline Feeding & Applicability & Viability & Cost & Total \\
\hline QFA & $7.80 \pm 0.45$ & $7.20 \pm 0.84$ & $8.20 \pm 0.84$ & $7.73 \pm 0.80$ \\
\hline 24-hour food recall & $4.80 \pm 1.10$ & $3.80 \pm 0.83$ & $6.80 \pm 2.17$ & $5.13 \pm 1.88$ \\
\hline RA & $3.60 \pm 1.67$ & $2.20 \pm 1.79$ & $5.00 \pm 2.55$ & $3.60 \pm 2.23$ \\
\hline Total & $6.15 \pm 2.28$ & $5.15 \pm 2.54$ & $6.95 \pm 2.06$ & \\
\hline MCA & \multicolumn{4}{|c|}{ Suggestion from the consensus workshop } \\
\hline VIGITEL & \multicolumn{4}{|c|}{ Suggestion from the consensus workshop } \\
\hline Anthropometry & Applicability & Viability & Cost & Total \\
\hline Height & $10.00 \pm 0.00$ & $10.00 \pm 0.00$ & $9.75 \pm 0.87$ & $9.91 \pm 0.52$ \\
\hline Body mass & $10.00 \pm 0.00$ & $10.00 \pm 0.00$ & $9.67 \pm 0.89$ & $9.88 \pm 0.52$ \\
\hline $\mathrm{BMI}$ & $9.83 \pm 0.38$ & $9.92 \pm 0.29$ & $9.67 \pm 0.87$ & $9.80 \pm 0.58$ \\
\hline Arm circumference & $9.25 \pm 1.29$ & $8.83 \pm 1.64$ & $10.00 \pm 0.00$ & $9.36 \pm 1.27$ \\
\hline Waist circumference & $9.41 \pm 0.90$ & $9.17 \pm 1.64$ & $10.00 \pm 0.00$ & $9.53 \pm 1.11$ \\
\hline Hip circumference & $10.00 \pm 1.29$ & $9.09 \pm 1.65$ & $10.0 \pm 0.00$ & $9.42 \pm 1.25$ \\
\hline WtHR & $9.08 \pm 1.62$ & $9.00 \pm 1.86$ & $9.67 \pm 0.78$ & $9.25 \pm 1.49$ \\
\hline Thigh circumference & $8.83 \pm 1.90$ & $8.08 \pm 2.11$ & $10.00 \pm 0.00$ & $8.97 \pm 1.78$ \\
\hline Biceps skinfold & $7.50 \pm 3.09$ & $6.58 \pm 3.15$ & $7.42 \pm 3.03$ & $7.17 \pm 3.03$ \\
\hline Subscapular skinfold & $7.17 \pm 3.01$ & $6.17 \pm 2.86$ & $7.41 \pm 3.03$ & $6.83 \pm 2.86$ \\
\hline Total & $8.98 \pm 1.89$ & $8.60 \pm 2.20$ & $9.20 \pm 2.00$ & \\
\hline
\end{tabular}

Note. BCS: Behavior Change Stage. FFQ: Food Frequency Questionnaire. R24h: 24-hour recall. FR: Food Register. FCM = Food Consumption Markers. BMI: Body Mass Index; WtHR: Waist-to-Hip ratio. 
from the matrix. Most instruments also showed higher average in the cost evaluation in relation to applicability and feasibility.

To assess anthropometry, waist circumference, BMI and body mass obtained the highest overall averages, being considered the most appropriate. Indicators and instruments with the best applicability were BMI and body mass. As for viability, the instrument with the highest average was body mass, while the instrument with the lowest cost was waist circumference. Thigh perimeter was the instrument with the lowest overall average and was the least viable.

Table 2 describes the averages of all assessment instruments for each item, in order of priority.

The last stage analyzed matrix composed of 12 instruments, four for physical activity, two for feeding and seven for anthropometry. In addition, 9.4\% of topics were not answered by G2 participants, justifying their lack of knowledge of the instrument, although they received the attachment with their description and average cost.

The fourth stage of the study was carried out with a focus group. Initially, the group analyzed the time that each professional has to evaluate participants, with time limit of 20 to 40 minutes.

Subsequently, the physical activity assessment instruments that would be feasible to apply to participants of the VAMOS program were discussed. In the end, the instruments chosen were the IPAQ short-version and the pedometer (donated by the VAMOS program) "Yes, IPAQ would be the

Table 2. Instruments selected in stage 3 to measure the effectiveness markers evaluated for use in the VAMOS program, in order of priority.

\begin{tabular}{|c|c|c|c|c|c|}
\hline Physical activity & Applicability & Viability & Cost & Total & SR $\%$ \\
\hline IPAQ short-version & $8.56 \pm 1.15$ & $8.81 \pm 1.11$ & $9.86 \pm 0.36$ & $9.04 \pm 1.09$ & 1.2 \\
\hline Baecke questionnaire & $7.38 \pm 1.56$ & $8.08 \pm 1.50$ & $9.50 \pm 0.90$ & $8.29 \pm 1.59$ & 4.7 \\
\hline 24-h physical activity recall & $7.00 \pm 2.67$ & $7.40 \pm 2.29$ & $8.29 \pm 2.64$ & $7.75 \pm 2.61$ & 1.2 \\
\hline Pedometer & $8.00 \pm 1.93$ & $7.81 \pm 1.87$ & $6.88 \pm 2.39$ & $7.56 \pm 2.09$ & 1.2 \\
\hline IPAQ short-version & $6.94 \pm 2.14$ & $6.75 \pm 2.52$ & $8.71 \pm 2.67$ & $7.41 \pm 2.54$ & 1.2 \\
\hline Total & $7.59 \pm 2.01$ & $7.76 \pm 2.01$ & $8.70 \pm 2.29$ & & 9.4 \\
\hline Feeding & Applicability & Viability & Cost & Total & $\mathrm{SR} \%$ \\
\hline VIGITEL & $8.50 \pm 1.17$ & $8.92 \pm 0.99$ & $8.64 \pm 2.59$ & $7.86 \pm 0.92$ & 5.9 \\
\hline FFQ & $7.43 \pm 1.87$ & $7.64 \pm 2.10$ & $8.46 \pm 2.66$ & $7.73 \pm 0.80$ & 9.8 \\
\hline FCM & $6.79 \pm 3.09$ & $7.64 \pm 2.10$ & $8.45 \pm 2.90$ & $7.73 \pm 0.80$ & 5.9 \\
\hline Total & $7.22 \pm 2.46$ & $7.48 \pm 2.61$ & $8.23 \pm 2.90$ & & 21.6 \\
\hline Anthropometry & Applicability & Viability & Cost & Total & SR \% \\
\hline Waist circumference & $9.41 \pm 0.80$ & $9.53 \pm 0.80$ & $9.67 \pm 0.49$ & $9.53 \pm 0.71$ & 0.0 \\
\hline BMI & $9.70 \pm 0.59$ & $9.59 \pm 0.71$ & $8.80 \pm 2.57$ & $9.39 \pm 1.54$ & 0.0 \\
\hline Body mass & $9.70 \pm 0.59$ & $9.65 \pm 0.70$ & $8.75 \pm 2.08$ & $9.38 \pm 1.34$ & 0.0 \\
\hline Height & $8.88 \pm 2.45$ & $9.53 \pm 0.80$ & $8.81 \pm 2.26$ & $9.08 \pm 1.96$ & 0.0 \\
\hline Arm circumference & $8.53 \pm 2.40$ & $9.12 \pm 1.02$ & $9.67 \pm 0.49$ & $9.08 \pm 1.61$ & 0.0 \\
\hline Hip circumference & $8.59 \pm 2.43$ & $9.06 \pm 0.99$ & $9.67 \pm 049$ & $9.08 \pm 1.61$ & 0.0 \\
\hline WtHR & $8.82 \pm 2.46$ & $9.31 \pm 1.01$ & $9.64 \pm 0.63$ & $9.23 \pm 1.63$ & 0.0 \\
\hline Thigh circumference & $9.67 \pm 0.50$ & $8.37 \pm 2.50$ & $8.73 \pm 1.22$ & $8.91 \pm 1.73$ & 0.7 \\
\hline Total & $9.01 \pm 1.98$ & $9.33 \pm 0.94$ & $9.32 \pm 1.52$ & & 0.7 \\
\hline
\end{tabular}

Note. SR: No answer. R24h: 24-hour recall. FFQ: Food Frequency Questionnaire. FCM = Food Consumption Markers. BMI: Body Mass Index; WtHR: Waist-to-Hip ratio. 
best of these, coupled with the pedometer, which is an instrument already used at VAMOS. I suggest combining these two instruments" (P1).

The difficulty of professionals in indicating a viable physical activity assessment instrument to be applied in UBS led to a consensus that a tutorial video teaching step by step how to apply the instruments would be needed. "Would it be possible to make an IPAQ tutorial video? Bring the group together for everyone to watch the video" (P2).

In the third moment, the instruments to assess anthropometric indicators were discussed. The consensus occurred quickly due to the ease of application of the proposed measures. The instruments chosen were: body mass, height, BMI and waist circumference. "I think that those used in PSE (Health at School program), weight (body mass), height and BMI because these are already used, there would be just one more group." (P1). "Waist circumference, because then if the subject loses weight but gains muscle mass, BMI becomes worse" (P3).

At the last moment, discussion was about instruments for assessing feeding, which generated discussion due to the limitations of instruments. "It is also difficult to choose, there are many limitations! VIGITEL is long, only if the number of questions is reduced. I like FFQ but I find it difficult to compare" (P3).

Due to difficulties of choice, it was suggested to adapt VIGITEL, reducing it to a maximum of 15 questions, which were defined by a group of UBS nutritionists from Florianópolis, accompanied by the tutorial video. "How about adapting VIGITEL questions? Some nutritionists and I could discuss VIGITEL questions and adapt the questionnaire. What do you think?" (P3). "I think it is a good idea to reduce it to 10 and 15 questions because it is usually a question per minute or less" (P2).

After selecting instruments to measure physical activity, feeding and anthropometry in the focus group, the creation of an explanatory video to be used by multipliers of the VAMOS program was suggested.

\section{DISCUSSION}

Instruments and measures selected for use in the evaluation of participants in the VAMOS program were: in physical activity, the IPAQ short-version and pedometer, in feeding, the VIGITEL questionnaire; and, in anthropometry, waist circumference, body mass, height and BMI. The choice of such instruments and measures took place through several stages: systematic review, consensus workshop, analysis by experts from different regions of the country and focus group. Consensus techniques are used, most of the time, when there are no conformities of evaluations on a given subject, either due to the lack of information on the topic or controversies among authors 9 .

In the consensus workshop, it was observed that the majority of professionals had similar opinion regarding the best instrument to be applied in UBSs in order to verify the effectiveness of the VAMOS program. Professionals discussed about not having adequate instruments to be applied 
in the SUS context, both in the area of physical activity and in feeding. Professionals who work in UBS talked about the difficulties in finding suitable instruments for application. The financial resources for Brazilian primary care at SUS and the time available for each professional to serve users were discussed ${ }^{6,10}$. For them, the instruments presented are long and difficult to interpret, which makes their application even more difficult.

Regarding instruments chosen in physical activity, pedometer consists of capturing movements performed when walking in response to the vertical acceleration of the body, converting it into numbers of steps ${ }^{11}$. Despite not evaluating exercise intensity and the lack of precision in the evaluation of some activities, such as running, it has the advantage of being a non-invasive method, easy to administer - especially in large populations - and easy to interpret, both by professional and participant, with already established cutoff points ${ }^{12}$. Despite having higher cost compared to the questionnaire, pedometer was donated to UBS by the Program, which was decisive for its choice.

In literature, pedometer is recommended as a motivating tool, being a stimulus when counting the daily steps of participants, who tend to walk more. Corroborating this idea, and in order to increase physical activity in the adult population in Rockhampton / Australia, the "10,000 Steps Rockhampton" project was created - which encourages people to walk more when they use the pedometer ${ }^{13}$.

The IPAQ short-version was the second instrument selected for physical activity. IPAQ consists of two versions, long and short. It is an instrument that investigates various physical activity domains and its validity and reproducibility have been tested in 12 countries, including Brazil ${ }^{14}$. The short version verifies physical activity in general, regardless of different domains. It estimates the weekly time spent in moderate to vigorous physical activity performed for at least 10 continuous minutes ${ }^{15}$.

The fact that it is validated in Brazil and its low cost of application in large populations are among its advantages, while disadvantages include interpretation, which may overestimate or underestimate results. The short version has the possibility of measuring the total physical activity practiced in the previous week by intensity (mild-moderate-vigorous), which allows collecting information on the total physical activity practiced and intensity ${ }^{16}$.

The feeding consensus workshop was the longest and most difficult. There were difficulties for participants to identify a viable instrument for use in UBS; the difficulty in evaluating foods was the most debated.

The difficulty mentioned above is also found in literature. Authors highlighted the need to choose and use instruments to evaluate programs and actions carried out in Primary Health Care ${ }^{17}$. In the professional field, there are many doubts about the most appropriate instruments for assessing food consumption, both by nutritionists and other health professionals. This is because there is no gold standard instrument, which makes the choice of an appropriate evaluation method even more difficult ${ }^{18}$. The main reason that leads to the absence of a gold standard instrument is the limitations of each instrument ${ }^{19}$. 
The instrument selected to assess feeding was the VIGITEL questionnaire, in its food part. This questionnaire consists of a monitoring system with the main objective of monitoring the frequency and distribution of risk and protective factors for $\mathrm{CNCD}$ in Brazil, and was implemented by the Ministry of Health in $2006^{20}$.

The food part of the VIGITEL questionnaire was considered the most appropriate instrument to be applied in UBS because it is a viable and low-cost instrument applicable by any professional, requiring only a brief training ${ }^{21}$. The advantages of the VIGITEL questionnaire were adequate reproducibility and clarity of questions, while the disadvantage was low specificity; however, the authors recommended its use to verify factors associated with chronic diseases ${ }^{22}$. Another study recommended the use of the VIGITEL questionnaire, arguing that it provides approximate information on the total population, presenting low cost and shorter time for application ${ }^{23}$.

Food assessment was reviewed and performed by nutritionists working in NASF of Florianópolis, with 12 VIGITEL questions chosen for use in VAMOS.

Regarding anthropometry, there were no difficulties in choosing instruments. In the consensus workshop, most participants expressed similar opinions, facilitating final choices. Anthropometry has been widely used because it is easy to apply, interpret and used in several populations. It is commonly used in feeding action programs due to the understanding of professionals that knowledge about healthy eating leads to improvement in nutritional status, which can be verified through this type of measurement ${ }^{24}$. This fact justifies the ease with which measurements and anthropometric indicators were chosen throughout the stages.

In anthropometry, measurements chosen were body mass, height, waist circumference and BMI. Body mass is the body mass or volume dimension, being the sum of the organic and inorganic mass. Height shows body development and bone length. Waist perimeter is intended to assess body fat distribution, and its measurement is performed between the midline of the last rib and the iliac crest with the purpose of assessing body fat distribution. BMI (Body Mass Index) is the relationship between body mass in kilograms $(\mathrm{kg})$ and height in square meters $(\mathrm{m} 2)$. Its calculation is important to classify health risk according to age group, sex and age, especially since it is a marker of chronic non-communicable diseases due to the accumulation of abdominal body fat ${ }^{25}$.

These instruments were selected mainly because they have low-cost and are non-invasive, safe and easy to apply and interpret, despite having as limiting factor the possibility of errors in the measurement technique, equipment without calibration or failure in typing information ${ }^{26}$. Another reason that led to the choice of these anthropometric indicators is that most of these measures are already used routinely in UBS.

The reasons that led to the choice of the aforementioned instruments were the available time and scope of work of UBS professionals. The training structure of health professionals does not contribute to the conduction 
of multiprofessional work and adequate health training leads these professionals to work with permanent education ${ }^{27}$.

Health professionals point to an excessive demand in UBS. This generates high workload, compromising the participation in group activities between multidisciplinary teams and users ${ }^{28}$. Studies have shown that health professionals consider their workload excessive due to organizational failures, high demand for services for few professionals, search for consultations in offices and administrative activities related to the Family Health Strategy ${ }^{27,29}$. This reality shows that offering easy-to-apply and low-cost instruments is fundamental, as it facilitates the performance of professionals and allows monitoring the effectiveness of the program, reducing obstacles to VAMOS in UBS.

The problems reported above constitute barriers to carrying out health promotion programs in Primary Health Care, which was also identified by Borges ${ }^{6}$. When analyzing barriers to the implementation of the VAMOS program in UBS of Florianópolis / SC, participants pointed out the unavailability of support by the health team, overwork of professionals and budgetary difficulty of the service. Therefore, it is necessary to have instruments that are easy to interpret and apply in order to facilitate the work of professionals in UBS.

In this sense, evaluating participants before and after the application of a health promotion program is essential to find out if, in fact, the actions carried out brought the expected benefits for users, in addition to providing feedback to professionals. Evaluation is important in the development of support for decision-making processes and more effective strategies, since it contributes to the adoption of the best practices in the community, as well as in the allocation of financial resources ${ }^{30}$.

The study's limitations were: difficulty in finding instruments with good applicability, feasibility and low cost in the proposed areas; acceptance of UBS professionals to participate in the focus group (greater participation could expand the focus of discussion and choice of instruments); and lack of consensus in literature about viable instruments for application in UBS.

The choice of instruments is relevant in the context of VAMOS, since the measurement of effectiveness is a marker of actions performed and an important element of monitoring the quality of the program. It is understood that the analyses carried out by professionals in the different stages of the study improve not only VAMOS, but also serve as guidelines for other behavior change programs that may be included in SUS.

\section{CONCLUSIONS}

The results of this study have important implications for assessing the effectiveness of the VAMOS program in UBS. Evaluation measures must be easy to apply, feasible and have low cost, with applicability in different locations and financial resources and little time available of UBS professionals.

Evaluating health promotion programs is essential to verify whether 
they are effective and cause positive changes in the lives of users, but assessment instruments should be appropriate to their reality. The opinions of researchers and health professionals, directly involved in daily practice, show that the measures in literature are not appropriate for use in SUS, but that the efficient adaptation of these measures can facilitate their application and present significant and reproducible results.

The choice of assessment instruments is an important step for the VAMOS program, since measurement allows both to monitor user behavior and to evaluate the effectiveness of actions. In this context, the technical and scientific process carried out allows inferring that the VAMOS program uses and recommends the most appropriate instruments to measure its effectiveness in physical activity, feeding and anthropometry within criteria of applicability, feasibility and low cost.

\section{COMPLIANCE WITH ETHICAL STANDARDS}

\section{Funding}

This study was funded by the SUS Research Program (PPSUS / FAPESC / 2014 / TR / 2263, Benedetti-PI). Scholarship by the Coordination for the Improvement of Higher Education Personnel (CAPES)

\section{Ethical approval}

Ethical approval was obtained from the local Human Research Ethics Committee -Universidade Federal de Santa Catarina and protocol No.1.394.492 and 1.518.283 was written in accordance with standards set by the Declaration of Helsinki.

\section{Conflict of interest statement}

The authors have no conflict of interests to declare.

\section{Author Contributions}

Conceived and designed experiments: TRBB and MCS Performed experiments: MCS Analyzed data: MCS Contributed with reagents/materials/analysis tools: TRBB, MCS and CGR Wrote the paper: MCS, TRBB and CGR.

\section{REFERENCES}

1. Brasil. Ministério da Saúde. Secretaria de Vigilância em Saúde. Departamento de Análise de Situação de Saúde. Plano de ações estratégicas para o enfrentamento das doenças crônicas não transmissíveis (DCNT) no Brasil 2011-2022. Brasília: Ministério da Saúde/Secretaria de Vigilância em Saúde, 2011.

2. Malta DC, Silva MMA, Albuquerque GM, Amorim RCA, Rodrigues GBA, Silva TS, et al. Política Nacional de Promoção da Saúde, descrição da implementação do eixo atividade física e práticas corporais, 2006 a 2014. Rev Bras Ativ Fís Saúde 2014;19(3):286-299.

3. Benedetti TRB, Schwingel A, Gomez LSR, Chodzko-Zajko, W. Programa "VAMOS” (Vida Ativa Melhorando a Saúde): da concepção aos primeiros resultados. Rev Bras Cineantropom Desempenho Hum 2012;14(6):723-737. 
4. Glasgow RE, Vogt TM, Boles SM. Evaluating the public health impact of health promotion interventions: the RE-AIM framework. Am J Public Health 1999;89(9):1322-1327.

5. Almeida FA, Brito FA, Estabrooks PA. Modelo RE-AIM: Tradução e Adaptação cultural para o Brasil. Rev Fam Ciclos Vida Saúde Contexto Soc2013;1(1):6-16.

6. Borges LJ. Influência de um programa de exercício físico na saúde mental e na aptidão funcional de idosos usuários dos Centros de Saúde de Florianópolis. [Dissertação de Mestrado - Programa de Pós-graduação em Educação Física] Florianópolis (SC): Universidade Federal de Santa Catarina; 2009.

7. Silva MC. Instrumentos para medida de atividade física, alimentação e antropometria no programa Vida Ativa Melhorando a Saúde - VAMOS: opiniões dos especialistas e multiplicadores. [Dissertação de Mestrado - Programa de Pós-Graduação em Educação Física]. Florianópolis (SC): Universidade Federal de Santa Catarina; 2017.

8. Bardin L. Análise de conteúdo. São Paulo: Ed. 70; 2011.

9. Campos, R. T. O, Miranda L, Gama CAP, Ferrer AL, Dias AR, Gonçalves L, et al. Oficinas de construção de indicadores e dispositivos de avaliação: uma nova técnica de consenso. Estud Pesqui Psicol 2010;10(1):221-241.

10. Lima SAV, Silva MRF, Carvalho EMF, Cesse EAP, Brito ESV, Braga, JPR. Elementos que influenciam o acesso à atenção primária na perspectiva dos profissionais e dos usuários de uma rede de serviços de saúde do Recife. Physis Rev Saúde Colet 2015;25(2):635-656.

11. Colpani V, Oppermann, K, Spritzer PM. Association between habitual physical activity and lower cardiovascular risk in premenopausal, perimenopausal, and postmenopausal women: a population-based study. Menopause 2013;20(5):525-18 531.

12. Colpani V, Spritzer PM, Lodi AP, Dorigo GG, Miranda IAS, Hahn LB, et al. Atividade física de mulheres no climatério: comparação entre auto-relato e pedômetro. Rev Saúde Pública 2014;48( 2):258-265.

13. Hall S, Broad M, Corry K, Duncan M. 10,000 Steps Working Paper Series, Paper 18: Awareness of the 10,000 Steps Program across Queensland. Rockhampton: CQUniversity; 2014.

14. Craig CL, Marshall AL, Sjöström M, Bauman AE, Booth ML, Ainsworth BE, et al. International physical activity questionnaire: 12 -country reliability and validity. Med Sci Sports Exerc 2003;35(8):1381-1395.

15. Benedetti TB, Mazo GZ, Barros MVG. Application of the international physicalactivity questionnaire (IPAQ) for evaluation of elderly women: concurrent validityand test-retest reprodutibility. Rev Bras Cineantropom Desempenho Hum2004;12(1):25-34.

16. Benedetti TRB, Antunes PC, Rodrigues-Añez CR, Mazo GZ, Petroski EL.Reprodutibilidade e validade do Questionário Internacional de Atividade Física (IPAQ) em homens idosos. Rev Bras Med Esporte 2007, 13(1): 11-16.

17. Fracolli LA, Gomes MFP, Nabão FRZ, Santos MS, Cappellini VK, Almeida ACC. Instrumentos de avaliação da Atenção Primária à Saúde: revisão de literatura e metassíntese. Ciênc Saúde Colet 2014; 19(12):4851-4860.

18. Fisberg RM, Marchioni DML, Colucci ACA. Avaliação do consumo alimentar e da ingestão de nutrientes na prática clínica. Arq Bras Endocrinol Metabol 2009;53(5):617-24.

19. Menezes MC, Horta PM, Santos LC, Lopes ACS. Avaliação do consumo alimentar e de nutrientes no contexto da atenção primária à saúde. Ceres: Nutr Saúde 2011;6(3):175-190.

20. Ministério da Saúde. VIGITEL Brasil 2006. Vigilância de fatores de risco e proteção para doenças crônicas por inquérito telefônico: estimativas sobre freqüência e distribuição sócio-demográfica de fatores de risco e proteção para doenças crônicas nas capitais dos 26 estados brasileiros e no Distrito Federal em 2006. Brasília: Ministério da Saúde; 2007.

21. Brasil. Ministério da Saúde. Secretaria de Vigilância em Saúde. Secretaria de Atenção à Saúde. Política Nacional de Promoção da Saúde: PNPS: revisão da Portaria MS/GM no 687, de 30 de março de 2006 Brasília: Ministério da Saúde, 2015. 
22. Mendes LL, Campos SF, Malta DC, Bernal RTI, Sá NNB, Velásquez-Meléndez G. Validade e reprodutibilidade de marcadores do consumo de alimentos e bebidas de um inquérito telefônico realizado na cidade de Belo Horizonte (MG), Brasil. Rev Bras Epidemiol 2011;14(1):80-89.

23. Ferreira AD, César CC, Malta DC, Andrade ACS, Ramos CGC, Proietti FA, et al. Validade de estimativas obtidas por inquérito telefônico: comparação entre VIGITEL 2008 e Inquérito Saúde em Beagá. Rev Bras Epidemiol 2011;14(1):16-30.

24. França CJ, Carvalho VCHS. Estratégias de educação alimentar e nutricional na Atenção Primária à Saúde: uma revisão de literatura. Saúde Debate 2017; 41(114):932-948.

25. Petroski EL. Antropometria: Técnicas E Padronizações. Jundiaí: Fontoura, 2011.

26. Ferreira MCS, Negri F, Galesi LF, Detregiachi CRP, Oliveira MRM. Monitoramento nutricional em unidades de atenção primária à saúde. Rev Assoc Bras Nutr 2017; 8(1):37-45.

27. Sá TH, Velardi M, Florindo AA. Limites e potencialidades da educação dos trabalhadores de saúde da família para promoção da atividade física: uma pesquisa participativa. Rev Bras Educ Fís Esporte 2016;30(2):417-426.

28. Lopes AS, Vilar RLA, Melo RHV, França RCS. O acolhimento na Atenção Básica em saúde: relações de reciprocidade entre trabalhadores e usuários. Saúde Debate 2015; 39(104):114-123.

29. Soratto J, Pires DEP, Trindade LL, Oliveira JSA, Forte ECN, Melo TP. Insatisfação no trabalho de profissionais da saúde na estratégia saúde da família. Texto Contexto Enferm 2017;26(3):1-11.

30. Miclos PV, Calvo MCM, Colussi CF. Avaliação do desempenho das ações e resultados em saúde da atenção básica. Rev Saude Publica 2017; 51:86.

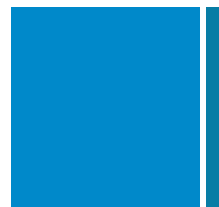

Corresponding author

Mônica Costa Silva

Rua Servidão Cereja, 266, Pantanal.

CEP: 88040-020.

Florianópolis, Santa Catarina, Brasil.

Email:monicacostaef@hotmail.com 